\title{
MECHANICAL PROPERTIES OF LIGHTWEIGHT FOAMED CONCRETE REINFORCED WITH RAW MESOCARP FIBRE
}

\author{
Md Azree Othuman Mydin
}

\author{
School of Housing, Building and Planning, Universiti Sains Malaysia, 11800, Penang, \\ Malaysia; azree@usm.my
}

\begin{abstract}
Lightweight foamed concrete (LFC) is recognised for its high flowability, minimal utilization of aggregates and superior heat insulation properties. LFC is excellent under compression but poor in tensile stress, as it produces multiple microcracks. LFC cannot withstand the tensile stress induced by applied forces without additional reinforcing elements. Hence, this study was conducted to examine the potential utilisation of oil palm pressed fibre (OPPF) reinforced LFC in terms of its mechanical properties. Two densities, $600 \mathrm{~kg} / \mathrm{m}^{3}$ and $1200 \mathrm{~kg} / \mathrm{m}^{3}$, were cast and tested with six different percentages of OPPF, which were $0.15 \%, 0.30 \%, 0.45 \%$ and $0.60 \%$. The parameters evaluated were compressive strength, flexural strength and tensile strength. The results revealed that the inclusion of $0.45 \%$ of OPPF in LFC helps to give the best results for the compressive strength, flexural strength and splitting tensile strength. The OPPF facilitated to evade the promulgation of cracks in the plastic state in the cement matrix when the load was applied.
\end{abstract}

\section{KEYWORDS}

Foamed concrete, Pressed fibre, Compression, Flexural, Water absorption, Porosity

\section{INTRODUCTION}

Lightweight foamed concrete (LFC) is characterised as a light cellular concrete with random air bubbles produced from the process of mixing foaming agent into the mortar [1]. LFC is known for its high flowability, low cement content, minimal use of aggregates, and superior heat insulation [2]. Moreover, LFC is deemed an economical alternative in the manufacture of large-scale lightweight construction materials and products, such as structural components, partitions, filling grades and road embankment infills, owing to its simple manufacturing process [3], which covers all stages from manufacturing plants to the final position of the applications [4]. LFC has a high degree of thermal insulation, which is a perfect material for use in passive house design [5]. It is undeniable that foam concrete is not reinforced as easily as traditional concrete, due to its low resistance to concentrated stress [5] and the difficulty of ensuring a sufficient bond of reinforcement [6]. LFC has a wide range of densities, from $300 \mathrm{~kg} / \mathrm{m}^{3}$ to $1900 \mathrm{~kg} / \mathrm{m}^{3}$, depending on its composition and the production machine used [7].

Some natural fibre, namely oil palm pressed fibre, is used in composites to develop lightweight, thermally insulated cement composites [8]. Oil palm pressed fibre (OPPF), also known as palm pressed fibre (PPF), is the residue of biomass produced after palm fruits are pressed for the extraction of palm oil [9]. After oil extraction, approximately 11 per cent of the OPPF is produced from palm fruits [9]. OPPF is generally made up of fabric, broken kernels and shells [10]. In mills, OPPF is currently primarily used as fuel for steam boilers [11,12]. As a lignocellulosic substance, OPPF has drawn researchers' interest because of its potential use in the development of biocomposites [13]. Natural fibre-reinforced composites have many advantages, such as being light 
weight, low-cost, highly durable, and with fair strength and rigidity [14,15]. OPPF acts as a reinforcement to improve its composites' behaviour [16].

There are some advantages of using fibre introduced into the concrete, such as the resulting composites offering more flexural strength compared to that of a reinforcement bar $[17,18]$. Besides, it will increase the impact toughness and post-failure integrity [19] and enhance the bending strength of the composites [20,21]. In addition, it will arrest the propagation of micro-cracks [22], the tensile strength of concrete increases and the air void and water voids reduce [23]. Hence, this research was carried out to determine the effect of the inclusion of OPPF on the mechanical properties of LFC.

\section{METHODS}

\section{Materials}

Cement

Ordinary Portland Cement was the cement used, in accordance with BS 12 Standard. Figure 3shows the OPC used in this research, which was supplied by YTL Castle Cement Marketing Sdn Bhd. All the cement used was in good condition and stored in a covered area. Table 1 shows the basic composition of OPC.

Tab. 1. - Composition of Ordinary Portland Cement (OPC) used in this study

\begin{tabular}{|c|c|}
\hline Chemical & Component (\%) \\
\hline Calcium Oxide, $\mathrm{CaO}$ & 62.91 \\
\hline Silicon Dioxide, $\mathrm{SiO} 2$ & 20.34 \\
\hline Aluminium (III) Oxide, $\mathrm{Al} 2 \mathrm{O} 3$ & 4.47 \\
\hline Iron (III) Oxide, $\mathrm{Fe} 2 \mathrm{O} 3$ & 4.58 \\
\hline Potassium Oxide, $\mathrm{K} 2 \mathrm{O}$ & 0.29 \\
\hline Magnesium Oxide, $\mathrm{MgO}$ & 1.24 \\
\hline Sodium Oxide, Na2O & 0.31 \\
\hline Sulphur Trioxide, SO3 & 2.58 \\
\hline Loss on ignition, LOI & 3.27 \\
\hline
\end{tabular}

\section{Fine Sand}

The fine aggregate used was natural fine sand obtained from a local distributor. It had to be prepared three days before casting, which meant that it had to be dried and sieved. If sand is ideally indicated in the blend design, it should be fine, with a maximum width of $2 \mathrm{~mm}$ and a 600 -micron sieve, and a passage of $60 \%$ to $90 \%$. The suitability of the sand had to follow BS822:1992. Figure 1 shows the sieve analysis result done on the fine sand utilized for this study. 


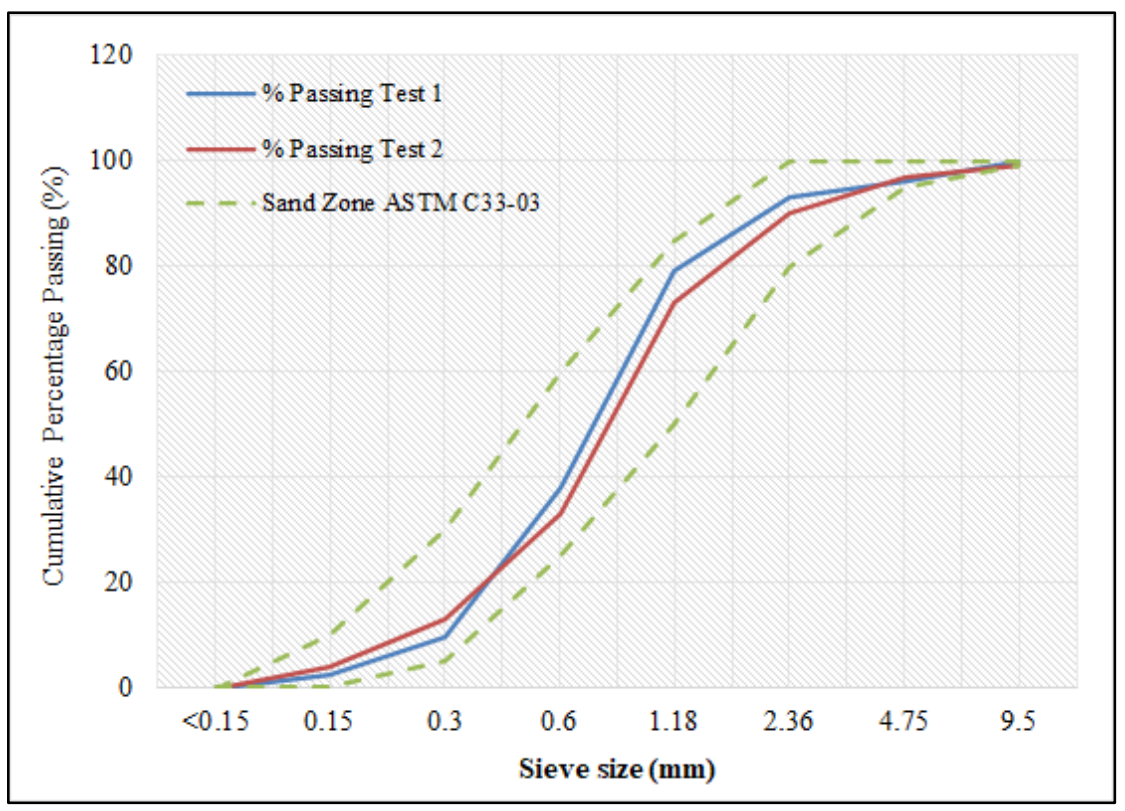

Fig. 1 - Sieve analysis result

\section{Foaming agent}

The foaming agent used in this study was a protein-based foaming agent, namely Noraite PA-1. The foam was produced by a portable foaming generator machine, namely the Portafoam TM1 machine. Noraite PA-1 was chosen as the forming agent due to its stability and smaller bubbles, which create a stronger bubble bonding structure compared to a synthetic-based protein.

\section{Water}

The water used had to be clear and clean. Water was required for the preparation of the mortar, mixing the foam concrete and the curing work. The water-cement ratio used for this research was 0.45 , because this ratio can achieve reasonable workability, based on previous research.

\section{Oil Palm Pressed Fibre}

The fibre used was OPPF, which was freshly collected from an industrial unit after processing. The OPPF was covered by a skin of grease which would cause fungus growth and spoilage. The fibre needed to be washed until it was free from the grease. The OPPF was placed under the sun to dry, as shown in Figure 2. Figure 3 visualizes the surface morphology details of OPPF structure.

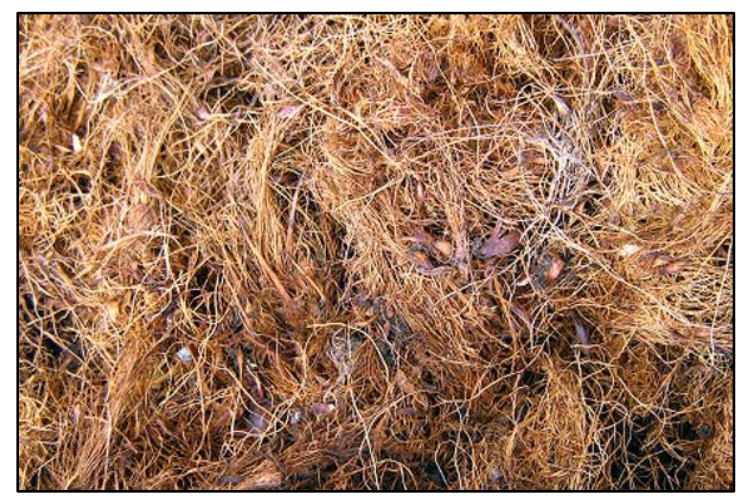

Fig. 2 - OPPF was placed under the sun in the drying process 


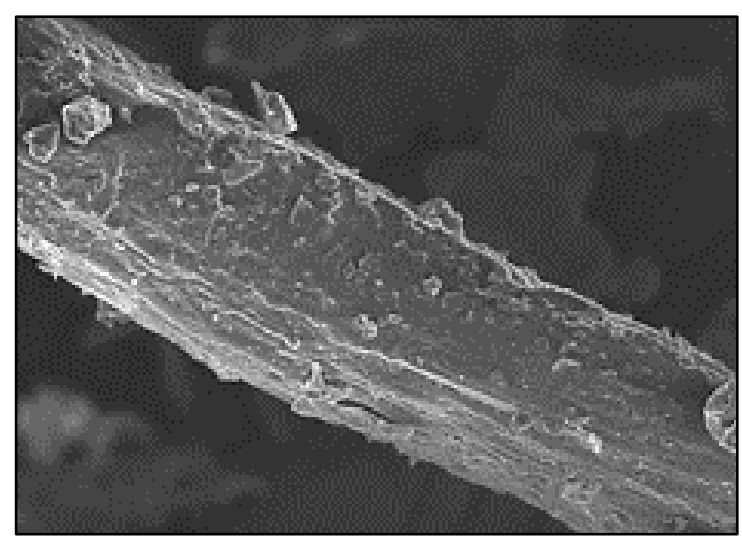

Fig. 3 - Surface morphology details of OPPF structure

The raw OPPF $x$-ray diffraction pattern is shown in Figure 4. It can be seen that the raw OPPF used for this research had diffraction patterns at around $2 \theta=23$ and $2 \theta=18$, which signified the crystalline and amorphous areas, correspondingly. Table 2 demonstrates the chemical composition and mechanical properties of single raw OPPF.

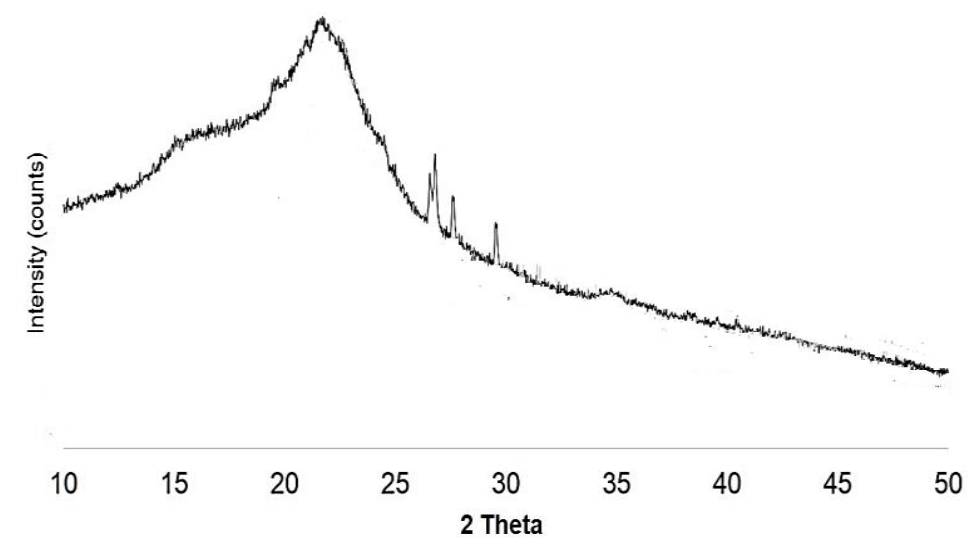

Fig. 4 - OPPF x-ray diffraction patterns

Tab. 2. - Chemical composition and mechanical properties of raw OPPF

\begin{tabular}{|c|c|}
\hline Lignin (\%) & $31.4 \pm 3.8$ \\
\hline Cellulose (\%) & $26.2 \pm 0.7$ \\
\hline Hemicellulose (\%) & $31.7 \pm 4.4$ \\
\hline Extractives (\%) & $4.3 \pm 0.2$ \\
\hline Tensile strength (N/mm²) & 139.6 \\
\hline Young's modulus (kN/mm²) & 14.3 \\
\hline Elongation at break (\%) & 9.76 \\
\hline
\end{tabular}

\section{Mix Design}

A total of 10 mixes and 2 densities, $600 \mathrm{~kg} / \mathrm{m}^{3}$ and $1200 \mathrm{~kg} / \mathrm{m}^{3}$, were prepared. The volume fractions of OPPF considered were $0.15 \%, 0.30 \%, 0.45 \%$ and $0.60 \%$. For all the mixes, the sand- 
cement ratio used was $1: 1.5$ and the water-cement ratio used was kept constant at 0.45 . Table 3 shows the mix proportions of this study.

Tab. 3: Mix proportions

\begin{tabular}{|c|c|c|c|c|c|c|}
\hline Mix & $\begin{array}{c}\text { OPMP } \\
(\%)\end{array}$ & $\begin{array}{c}\text { Density } \\
\left(\mathrm{kg} / \mathrm{m}^{3}\right)\end{array}$ & Cement $(\mathrm{kg})$ & $\begin{array}{c}\text { Sand } \\
(\mathrm{kg})\end{array}$ & $\begin{array}{c}\text { Water } \\
(\mathrm{kg})\end{array}$ & $\begin{array}{c}\text { Mix Ratio } \\
(\mathrm{C}: \mathrm{S}: \mathrm{W})\end{array}$ \\
\hline 1 & - & 600 & 20.72 & 31.09 & 9.32 & $1: 1.5: 0.45$ \\
\hline 2 & 0.15 & 600 & 20.72 & 31.09 & 9.32 & $1: 1.5: 0.45$ \\
\hline 3 & 0.30 & 600 & 20.72 & 31.09 & 9.32 & $1: 1.5: 0.45$ \\
\hline 4 & 0.45 & 600 & 20.72 & 31.09 & 9.32 & $1: 1.5: 0.45$ \\
\hline 5 & 0.60 & 600 & 20.72 & 31.09 & 9.32 & $1: 1.5: 0.45$ \\
\hline 6 & - & 1200 & 40.22 & 60.33 & 18.10 & $1: 1.5: 0.45$ \\
\hline 7 & 0.15 & 1200 & 40.22 & 60.33 & 18.10 & $1: 1.5: 0.45$ \\
\hline 8 & 0.30 & 1200 & 40.22 & 60.33 & 18.10 & $1: 1.5: 0.45$ \\
\hline 9 & 0.45 & 1200 & 40.22 & 60.33 & 18.10 & $1: 1.5: 0.45$ \\
\hline 10 & 0.60 & 1200 & 40.22 & 60.33 & 18.10 & $1: 1.5: 0.45$ \\
\hline
\end{tabular}

\section{Testing}

Tests were carried out investigating the mechanical and durability properties with the inclusion of OPPF. Destructive tests, which included compression tests, flexural tests and splitting tensile tests, were done to determine the mechanical properties of LFC. Table 4 shows the details of the specimens and standard codes referred to in these tests for the durability and mechanical properties. Figures 5, 6 and 7 demonstrate the setup for compression test, flexural test and splitting tensile test correspondingly.

Tab. 4: Mechanical properties tests

\begin{tabular}{|l|l|l|}
\hline Type of Test & Specimen & Standard \\
\hline Axial compression test & Cube $(100 \mathrm{~mm} \times 100 \mathrm{~mm} \times 100 \mathrm{~mm})$ & BS EN 12390-3: 2001 \\
\hline Flexural test & Prism $(100 \mathrm{~mm} \times 100 \mathrm{~mm} \times 500 \mathrm{~mm})$ & ASTM C 348 \\
\hline Splitting tensile test & Cylinder $(100 \mathrm{~mm}$ diameter $\times 200 \mathrm{~mm}$ height $)$ & ASTM C496/C 496M \\
\hline
\end{tabular}

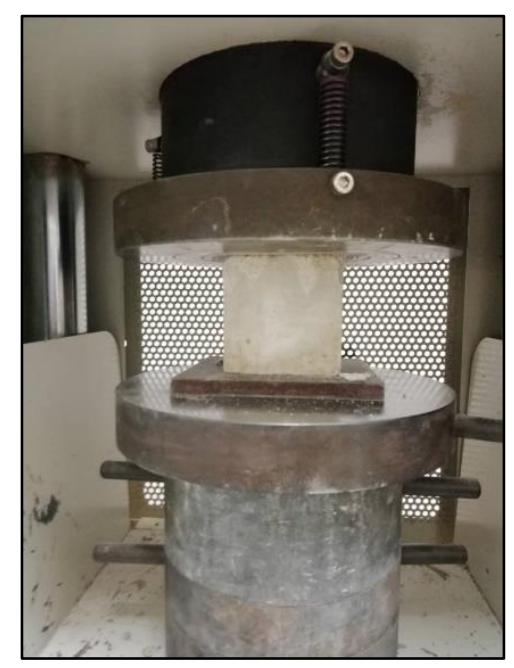

Fig. 5 - Compression test setup according to BS EN 12390-3: 2001 


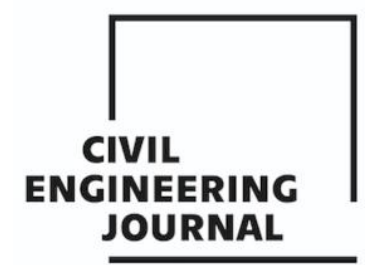

Article no. 47

THE CIVIL ENGINEERING JOURNAL 3-2021

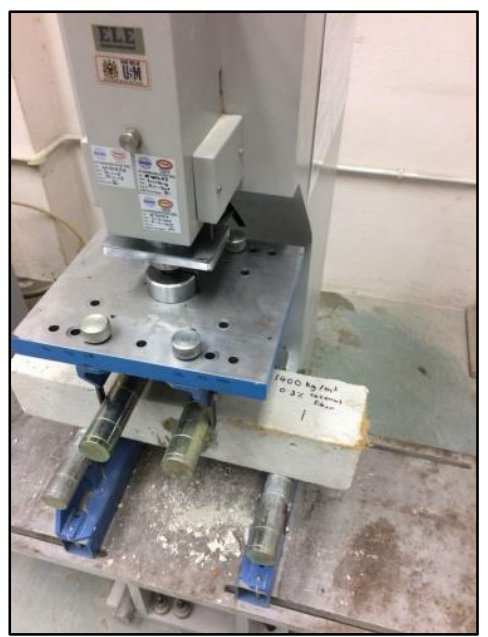

Fig. 6 - Flexural test setup according to ASTM C 348

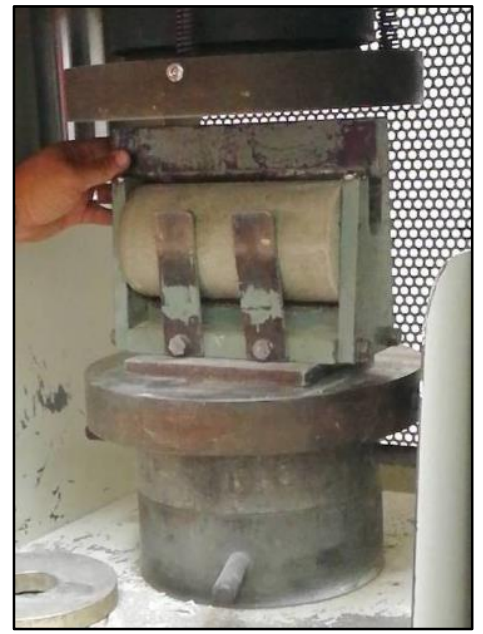

Fig. 7 - Splitting tensile test setup according to ASTM C496/C 496M

\section{RESULTS AND DISCUSSION}

\section{Compressive Strength}

Figures 8 and 9 show the results of the axial compressive strength test of both $600 \mathrm{~kg} / \mathrm{m}^{3}$ and $1200 \mathrm{~kg} / \mathrm{m}^{3}$ densities of LFC with the addition of different proportions of OPPF. There was an enhancement in the strength of the control until $0.45 \%$ of OPPF addition. The strength reduced when $0.60 \%$ of OPPF was added. The factor that led to the decreasing value of fibre reinforced LFC was the interruption of fibre presence. Next, the highest compressive strength for both densities was at day-56, compared to day-7 and day-28. For the density of $600 \mathrm{~kg} / \mathrm{m}^{3}$, the highest compressive strength was $1.61 \mathrm{~N} / \mathrm{mm}^{2}$ at day-56 with the addition of $0.45 \%$ of OPPF. The lowest compressive strength was $0.89 \mathrm{~N} / \mathrm{mm}^{2}$ with the addition of $0.60 \%$ of OPPF at day-7. For the density of $1200 \mathrm{~kg} / \mathrm{m}^{3}$, the highest compressive strength was $5.82 \mathrm{~N} / \mathrm{mm}^{2}$ at day-56 with the addition of $0.45 \%$ of OPPF. The lowest compressive strength was $3.22 \mathrm{~N} / \mathrm{mm}^{2}$, which was for plain LFC at day-7. At day-28, the strength of the control specimen of $600 \mathrm{~kg} / \mathrm{m}^{3}$ density increased from $1.16 \mathrm{~N} / \mathrm{mm}^{2}$ to $1.24 \mathrm{~N} / \mathrm{mm}^{2}$, $1.30 \mathrm{~N} / \mathrm{mm}^{2}$ and $1.44 \mathrm{~N} / \mathrm{mm}^{2}$, when $0.15 \%, 0.30 \%$ and $0.45 \%$ of OPPF was added, respectively. For the $1200 \mathrm{~kg} / \mathrm{m}^{3}$ density, the strength of the control specimen was $3.68 \mathrm{~N} / \mathrm{mm}^{2}$, and it increased to $4.61 \mathrm{~N} / \mathrm{mm}^{2}, 4.77 \mathrm{~N} / \mathrm{mm}^{2}$ and $5.35 \mathrm{~N} / \mathrm{mm}^{2}$ when $0.15 \%, 0.30 \%$ and $0.45 \%$ of OPPF was added, 
correspondingly. This shows that the addition of OPPF increases the compressive strength of LFC accordingly. There was a massive enhancement in strength from day-7 to day-90. When the OPPF volume fraction exceeds $0.45 \%$, the compressive strength of LFC reduced intensely, as evidenced by other studies. According to Thakrele [24], the inclusion of high-volume fraction of natural fibre in LFC will impede the hydration process, consequently causing in low strength concrete. As LFC comprises void gaps of a wide range of sizes and shapes in the cement matrix and micro-cracks at the transition zone between the matrix, the inclusion of fibre can assist in the failure of the mode under compression stress [25].

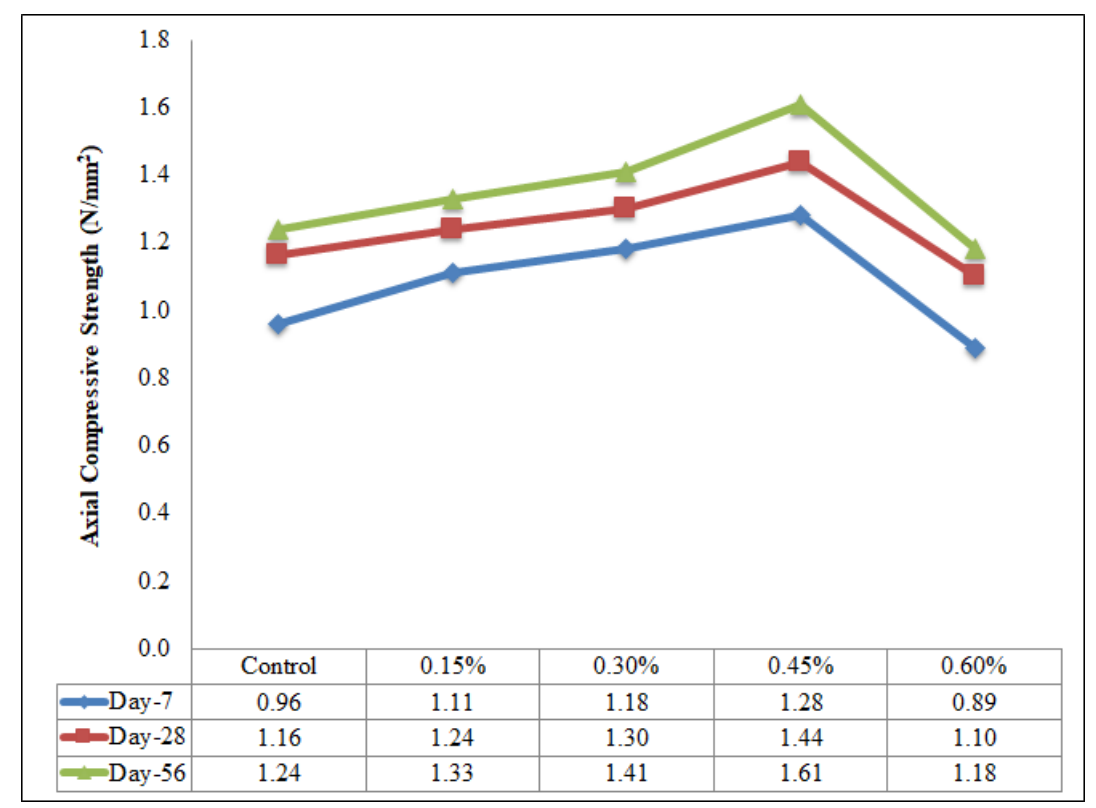

Fig. 8 - Influence of different percentages of OPPF on axial compressive strength of $600 \mathrm{~kg} / \mathrm{m}^{3}$ density $L F C$

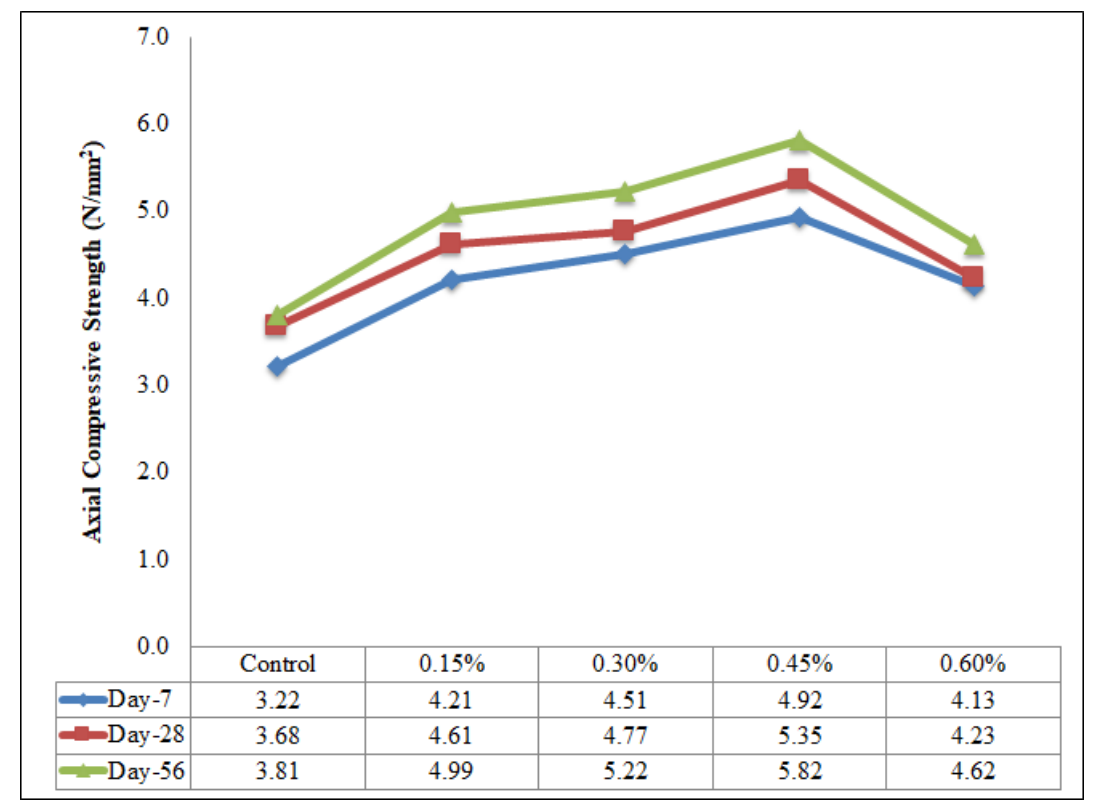

Fig. 9 - Influence of different percentages of OPPF on axial compressive strength of $1200 \mathrm{~kg} / \mathrm{m}^{3}$ density $L F C$ 


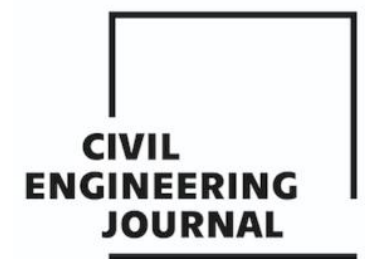

Article no. 47

THE CIVIL ENGINEERING JOURNAL 3-2021

Figure 10 shows the scanning electron microscopy result of fractured surface of LFC strengthened with OPPF. Although addition of OPPF plays and important role to enhance the interfacial adhesion between cement paste and the OPPF, the evidence of pull-out of fibre can be clearly seen under compressive load especially for lower density LFC $\left(600 \mathrm{~kg} / \mathrm{m}^{3}\right)$. Lower density which consists of large pores unable to withstand additional load under compressive due to poor adhesion. Anyhow, the addition of OPPF in LFC assisted in bounding the LFC matrix in lateral direction, thus improved the confinement effect and indirectly improved the compressive strength of LFC when the specimens were compressed.

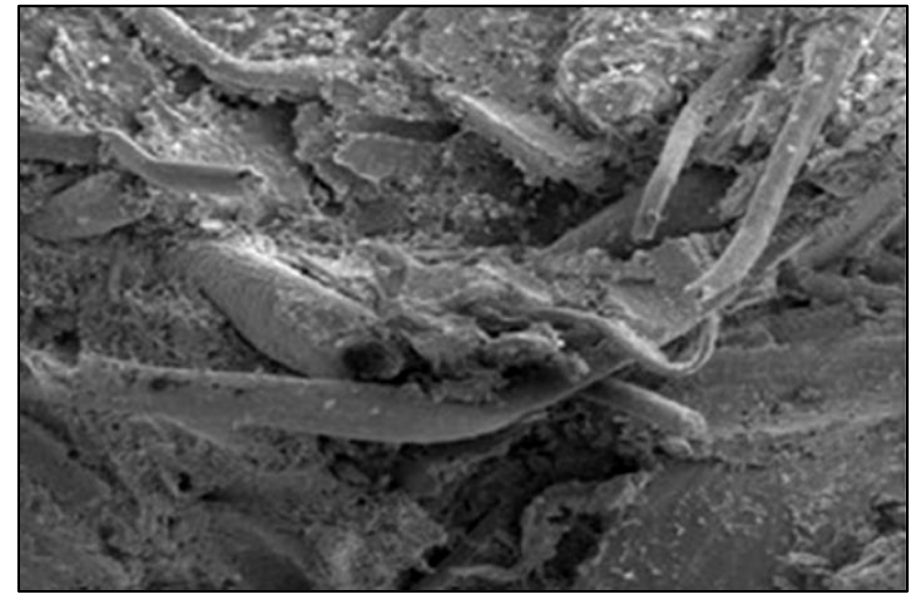

Fig. 10 - SEM image of fractured surface of $600 \mathrm{~kg} / \mathrm{m}^{3}$ density LFC under compression load

\section{Flexural Strength}

Figure 11 and Figure 12 show the results of the flexural strength test of both densities of LFC, $600 \mathrm{~kg} / \mathrm{m}^{3}$ and $1200 \mathrm{~kg} / \mathrm{m}^{3}$. The flexural strength rose noticeably from the control up to the addition of $0.45 \%$ of OPPF. The improvement in the flexural strength of the LFC was attributed to the fact that the fibre behaves as a reinforcing layer that connects the grid of the cementitious matrix in a durable manner relative to the specimen, without any fibre being added in the tensile zone. Meanwhile, the flexural strength declined when $0.60 \%$ of OPPF was added. The reason for the decrease in the value of the fibre reinforced LFC was the interruption of fibre presence [26]. Next, the highest flexural strength was recorded for both densities at day-56, compared to day-7 and day-28. For the density of $600 \mathrm{~kg} / \mathrm{m}^{3}$, the highest flexural strength was $0.37 \mathrm{~N} / \mathrm{mm}^{2}$ at day-56 with the addition of $0.45 \%$ of OPPF. The lowest flexural strength was $0.9 \mathrm{~N} / \mathrm{mm}^{2}$ without any proportion of OPPF at day-7. For the density of $1200 \mathrm{~kg} / \mathrm{m}^{3}$, the highest flexural strength was $1.28 \mathrm{~N} / \mathrm{mm}^{2}$ at day-56 with the addition of $0.45 \%$ of OPPF. The lowest flexural strength recorded was $0.72 \mathrm{~N} / \mathrm{mm}^{2}$, which was found in the plain LFC at day-7. It can be seen that for both densities, plain LFC attained a lower flexural strength compared to the LFC with the addition of OPPF. The reason for the increase in flexural strength was the fracture process of the fibre, which derived from the progressive debonding of the fibre that slowed the crack propagation [27]. According to Musa et al. [28], the flexural strength of LFC ranges between $15 \%$ and $35 \%$ of its compressive strength. Whereas in the current research, the flexural strength of LFC is between 18-30\% of its compressive strength. The OPPF in LFC is to strengthen FC mass and transfer the basic material character from brittle to ductile elastic-plastic. OPPF contributes towards enhancing the flexural strength of LFC. Though, disproportionate OPPF volume fraction may also lead to reducing bonding and deteriorating [29]. The use of a $0.45 \%$ volume fraction of OPPF can be considered an optimal percentage for this type of concrete based on the increment of flexural strength. The enhancement of flexural strength is compatible with the compressive strength upsurge. Elevated flexural strength is due to the reduction of porosity in LFC mixes. 


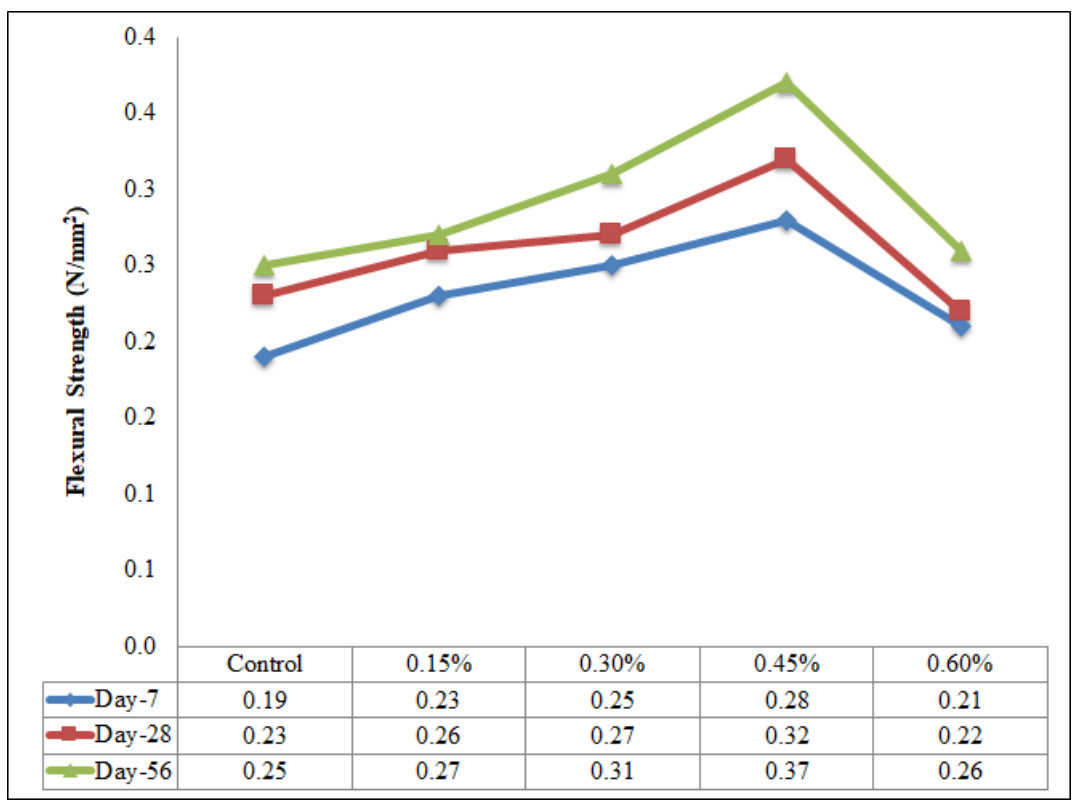

Fig. 11 - Influence of different percentages of fibre on flexural strength of $600 \mathrm{~kg} / \mathrm{m}^{3}$ density

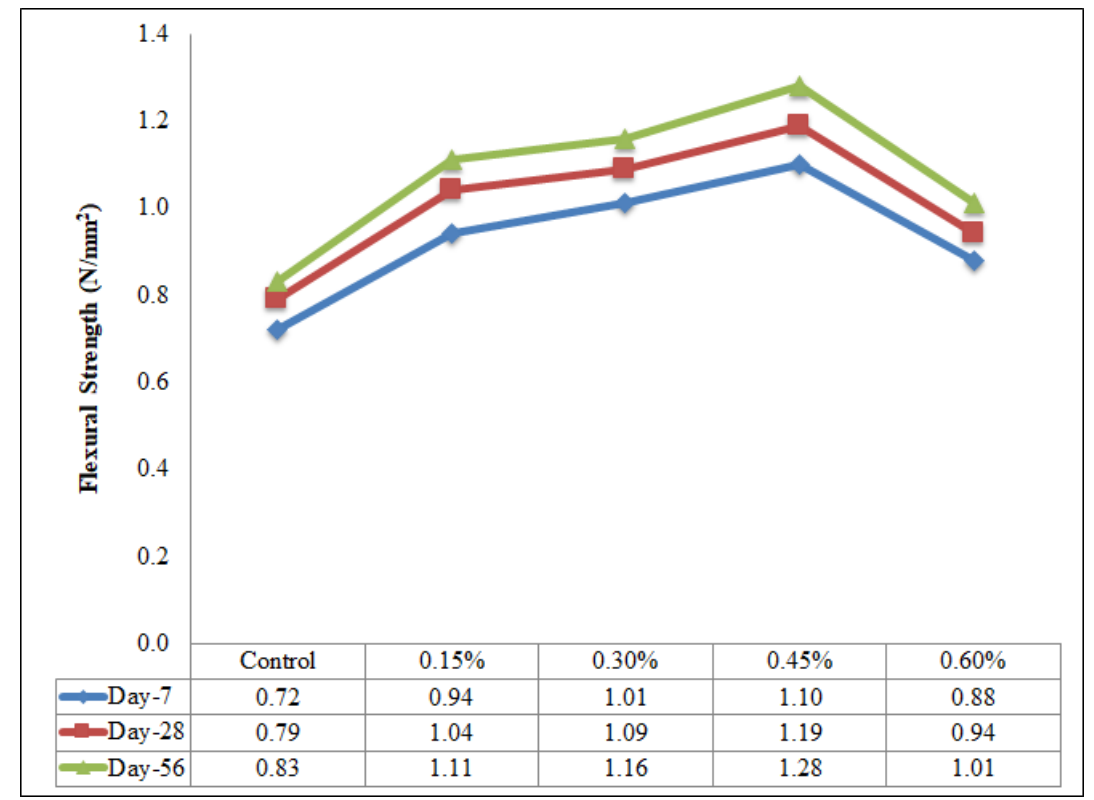

Fig. 12 - Influence of different percentages of fibre on flexural strength of $1200 \mathrm{~kg} / \mathrm{m}^{3}$ density

Figure 13 visualizes the scanning electron microscopy result of fractured surface of LFC strengthened with OPPF under flexural load. As far as flexural load is concern, there was very little indication of OPPF retreat occurred signifying the stress which was transferred to the OPPF in the cementitious composite was stronger resulting in OPPF rupture rather than principally fibre pull-out. 


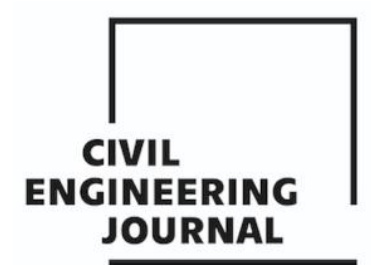

Article no. 47

THE CIVIL ENGINEERING JOURNAL 3-2021

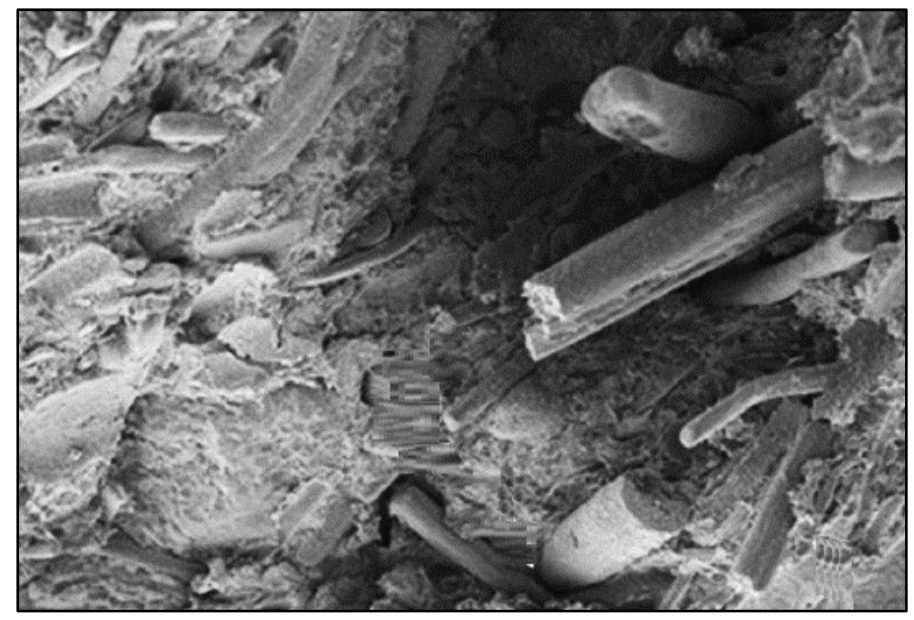

Fig. 13 - SEM image of fractured surface of $600 \mathrm{~kg} / \mathrm{m}^{3}$ density LFC under flexural load

\section{Splitting Tensile Strength}

Figures 14 and 15 display the trend concerning the development of the splitting tensile strength of LFC. The splitting tensile strength rose visibly from the control up to the inclusion of $0.45 \%$ of OPPF. The trend of the growth in the splitting tensile strength of LFC with the inclusion of OPPF was attributed to the elasticity of the fibre, which can stretch and bond strongly with the cement matrix to avoid cracking [30]. Subsequently, the splitting tensile strength dropped when $0.60 \%$ of OPPF was added. For the $600 \mathrm{~kg} / \mathrm{m}^{3}$ density, the highest splitting tensile strength was $0.21 \mathrm{~N} / \mathrm{mm}^{2}$, which was at day-56 with the inclusion of $0.45 \%$ OPPF. The lowest splitting tensile strength was $0.09 \mathrm{~N} / \mathrm{mm}^{2}$, which was the plain LFC at day-7. For the $1200 \mathrm{~kg} / \mathrm{m}^{3}$ density, the highest splitting tensile strength was $0.78 \mathrm{~N} / \mathrm{mm}^{2}$ at day-56 with the addition of $0.45 \%$ OPPF. The lowest splitting tensile strength was $0.32 \mathrm{~N} / \mathrm{mm}^{2}$, which was the plain LFC at day-7. The splitting tensile strength of LFC attained in this investigation is about $60 \%$ of its flexural strength. As shown in Table 1, the elongation at break for mesocarp fibre is considered minimal (9.76\%), resulting in high tensile strength [31]. Elongation at break expresses the ability of fibre to resist changes of shape without crack formation. Natural fibre such as oil palm fibre is more rigid, thus contributes to enhancing the splitting tensile strength [32]. LFC is known to have low tensile strength and brittle nature. Though, based on the data recorded in this study, the tensile strength was shown to increase due to the presence of OPPF. The increase of tension strength is due to the increase in toughness of concrete due to the presence of OPPF where $0.45 \%$ of fibre content addition enhances the increment of tensile strength in FC by promoting optimum pozzolanic reaction with OPC content, thus producing denser and stronger concrete. 


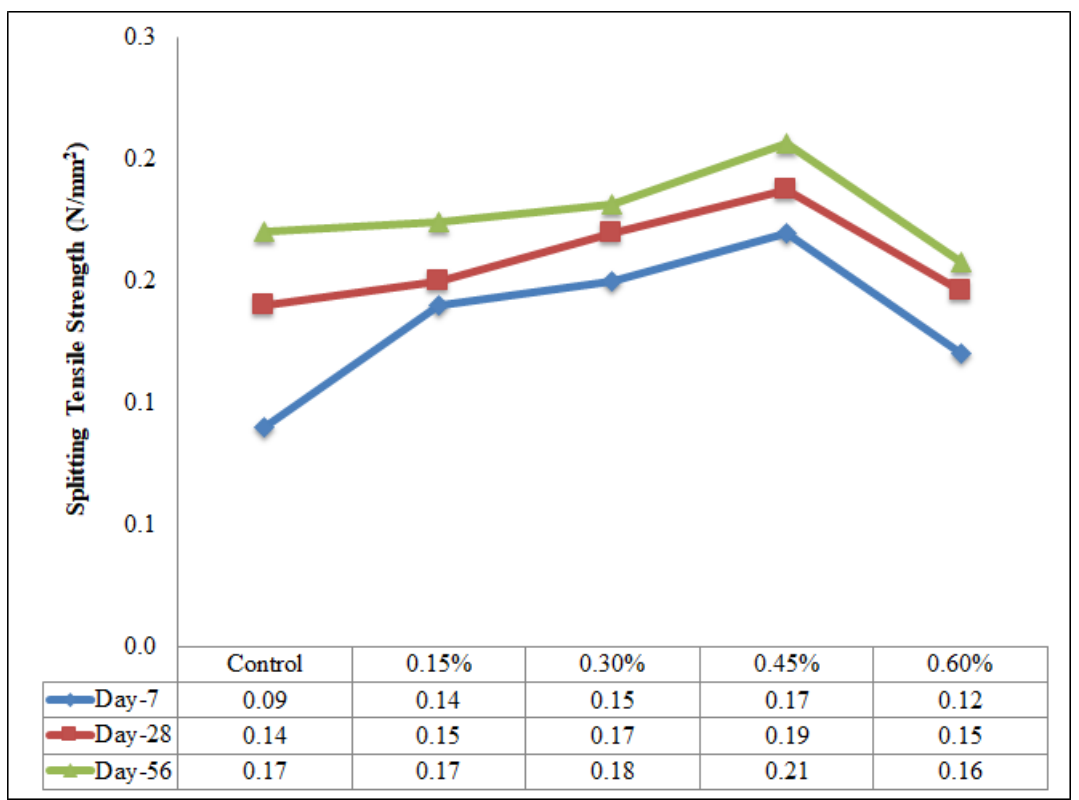

Fig. 14 - Influence of different percentages of fibre on tensile strength of $600 \mathrm{~kg} / \mathrm{m}^{3}$ density LFC

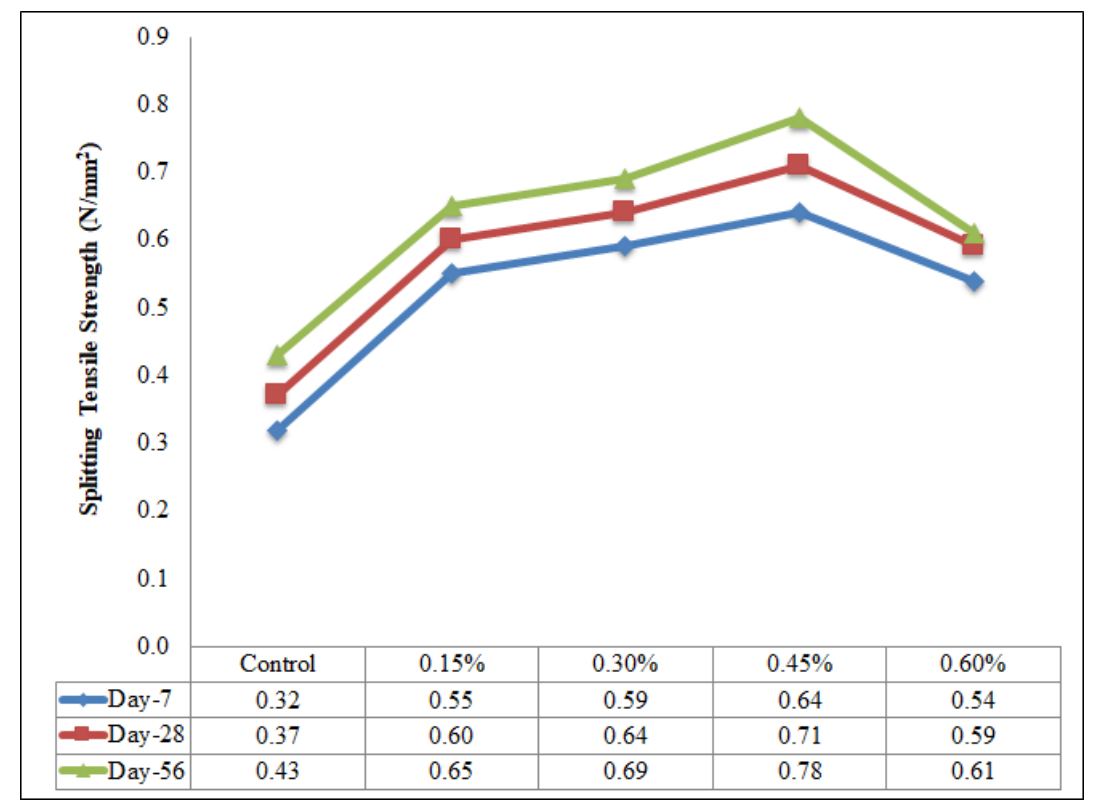

Fig. 15 - Influence of different percentages of fibre on tensile strength of $1200 \mathrm{~kg} / \mathrm{m}^{3}$ density LFC

Figure 16 demonstrates the scanning electron microscopy result of fractured surface of LFC reinforced with OPPF under tensile load. It can be seen that fibre pull-out was little compared to fibre breakage. There was an effective transfer of tensile stress from one member to another in LFC composites for both densities considered in this research. There was also excellent interphase between the OPPF and the cementitious matrix of LFC. The inclusion of OPPF in LFC aided in bounding the LFC cementitious matrix in transverse direction, thus enhanced the internment effect and circuitously enhanced the tensile strength of LFC. 


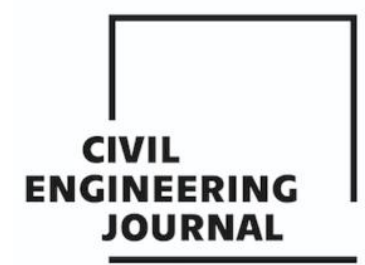

Article no. 47

THE CIVIL ENGINEERING JOURNAL 3-2021

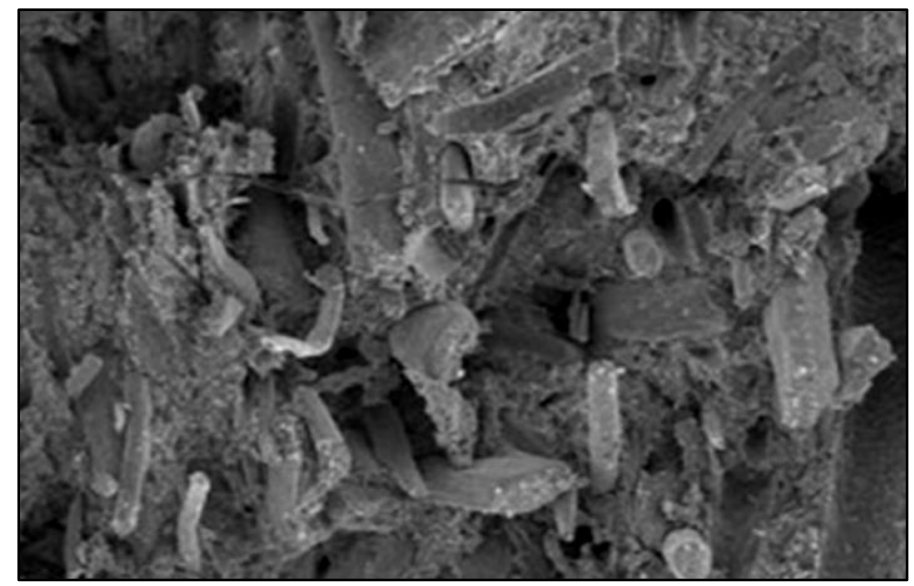

Fig. 16 - SEM image of fractured surface of $600 \mathrm{~kg} / \mathrm{m}^{3}$ density LFC under tension

\section{CONCLUSION}

In the study, the mechanical properties with the addition of different proportions of OPPF into different densities of LFC were investigated. Two densities of LFC, $600 \mathrm{~kg} / \mathrm{m}^{3}$ and $1200 \mathrm{~kg} / \mathrm{m}^{3}$, were prepared and tested with five different percentages of OPPF added, which were $0 \%, 0.15 \%, 0.30 \%$, $0.45 \%$ and $0.60 \%$. The results show that the best outcomes, in terms of mechanical properties, were obtained with the $1200 \mathrm{~kg} / \mathrm{m}^{3}$ density with the $0.45 \%$ addition of OPPF. This achieved the highest strength (compressive, flexural and splitting tensile), The OPPF helped to avoid the promulgation of cracks in the plastic state in the cement matrix when the load was applied.

\section{REFERENCES}

[1] Araya-Letelier G., Antico F.C., Carrasco M., Rojas P., García-Herrera C.M., 2017. Effectiveness of new natural fibres on damage-mechanical performance of mortar. Construction and Building Materials, vol. 152: 672-682.

[2] Mydin M.A.O., Phius A.F., Sani N.M., Tawil NM., 2014. Potential of Green Construction in Malaysia: Industrialised Building System (IBS) vs Traditional Construction Method. E3S Web of Conferences, vol. 3: 01009

[3] Liew K.M., Sojobi A.O., Zhang L.W., 2017. Green concrete: Prospects and challenges, Construction and Building Materials, vol. 156: 1063-1095

[4] Mydin M.A.O, Nawi, M.N.M., Munaaim M.A.C., Mohamad N., Samad, A.A.A., Johari I., 2018. Effect of steel fibre volume fraction on thermal performance of Lightweight Foamed Mortar (LFM) at ambient temperature. Journal of Advanced Research in Fluid Mechanics and Thermal Sciences, vol. 47(1): 119-126

[5] Hegyi A., Dico C., Catalan G., 2016. Construction sustainability with adobe bricks type elements. Urbanism, Architecture and Construction, vol. 7(2): 147-156

[6] Ardanuy M., Claramunt J., Toledo Filho R.D., 2015. Cellulosic fibre reinforced cement-based composites: A review of recent research. Construction and Building Materials, vol. 79: 115-128

[7] Othuman Mydin M.A., 2016. Evaluation of splitting tensile strength in plain and fibre-reinforced foamed mortar. Jurnal Teknologi, vol. 78(5): 413-419

[8] Serri E., Suleiman M.Z., Mydin M.A.O., 2014. The effects of oil palm shell aggregate shape on the thermal properties and density of concrete. Advanced Materials Research, vol. 935: 172-175

[9] Othuman Mydin M.A., Mohamed Shajahan M.F., Ganesan S., Sani N.M., 2014. Laboratory investigation on compressive strength and micro-structural features of foamed concrete with addition of wood ash and silica fume as a cement replacement. MATEC Web of Conferences, vol. 17: 01004

[10] Nechyporchuk O., Belgacem M.N., Bras J., 2016. Production of cellulose nanofibrils: A review of recent advances. Industrial Crops \& Products, vol. 93: 2-25. 


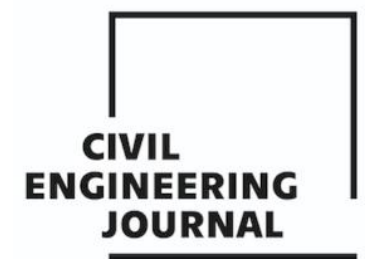

Article no. 47

THE CIVIL ENGINEERING JOURNAL 3-2021

[11] Othuman Mydin M.A., 2015. Effect of silica fume and wood ash additions on flexural and splitting tensile strength of lightweight foamed concrete. Jurnal Teknologi, vol. 74(1): 125-129

[12] Othuman Mydin M.A., Potential of natural and synthetic fibres on flexural performance of foamcrete mortar, Jurnal Teknologi, vol. 78(5): 431-435

[13] Faruk O., Bledzki A.K., Fink H.P., Sain M., 2012. Biocomposites reinforced with natural fibres: 20002010. Progress in Polymer Science, vol. 37(11): 1552-1596.

[14] Jawaid M., Abdul Khalil H.P.S., 2011. Cellulosic/synthetic fibre reinforced polymer hybrid composites: A review, Carbohydrate Polymers, vol. 86(1): 1-18.

[15] Mydin M.A.O., Zamzani N.M., Ghani A.N.A., 2018. Effect of alkali-activated sodium hydroxide treatment of coconut fibre on mechanical properties of lightweight foamed concrete, in 3rd International Conference on Applied Science and Technology, vol. 5055512: 020108.

[16] Jiang D., Cui S., Xu F., Tuo T., 2015. Impact of leaf fibre modification methods on compatibility between leaf fibres and cement-based materials, Construction and Building Materials, vol. 94: 502-512.

[17] Wei J., Meyer C., 2016. Utilization of rice husk ash in green natural fibre-reinforced cement composites: Mitigating degradation of sisal fibre. Cement and Concrete Research, vol. 81: 94-111.

[18] Mydin M.A.O., 2017. Preliminary studies on the development of lime-based mortar with added egg white. International Journal of Technology, vol.8(5): 800-810

[19] Othuman Mydin, M.A., Zamzani, N.M., Ghani, A.N.A., 2019. Experimental data on compressive and flexural strengths of coir fibre reinforced foamed concrete at elevated temperatures, Data in Brief, vol. 25, 104320

[20] Mydin M.A.O., Musa M., Ghani A.N.A., 2018. Fiber glass strip laminates strengthened lightweight foamed concrete: Performance index, failure modes and microscopy analysis. AIP Conference Proceedings, vol. 2016: 020111

[21] Mohan N.H., Ammayappan L., Sarma D.K., Debnath S., Tamuli M.K., 2017. Characterization of thermal properties of pig hair fibre, Journal of Natural Fibres, vol. 14(4): 1-7.

[22] Ganesan S., Othuman Mydin M.A., Sani N.M., Che Ani A.I., 2014. Performance of polymer modified mortar with different dosage of polymeric modifier. MATEC Web of Conferences, vol. 15: 01039

[23] Bentur A., Mindess S., 2006. Fibre Reinforced Cementitious Composites. CRC Press, Second edition, New York, p. 48-51

[24] Thakrele, M. H., 2014. Experimental study on foam concrete. International Journal of Civil, Structural, Environmental and Infrastructure Engineering Research and Development, 4(1), 145-158.

[25] Othuman Mydin M.A., 2016. Experimental investigation of axial compressive strength of lightweight foamed concrete with different additives, Jurnal Teknologi, vol. 78(5): 463-469

[26] Othuman Mydin M.A., Mohamad N., Johari I., Abdul Samad A.A., 2018. Determination of bending and axial compression young's modulus of cellular mortar exposed to high temperatures, International Journal of Engineering and Technology (UAE), vol. 7(2): 99-102

[27] Suhaili S.S., Mydin M.A.O., 2020. Potential of stalk and spikelets of empty fruit bunch fibres on mechanical properties of lightweight foamed concrete, International Journal of Scientific and Technology Research, vol. (3): 3199-3204

[28] Musa M., Othuman Mydin M.A., Abdul Ghani A.N., 2019. Thermal properties of foamed concrete with addition of empty fruit bunch (EFB) fiber. International Journal of Innovative Technology and Exploring Engineering, vol. 8(10): 4662-4670

[29] Othuman Mydin M.A., 2016. Assessment of thermal conductivity, thermal diffusivity and specific heat capacity of lightweight aggregate foamed concrete. Jurnal Teknologi, vol. 78(5): 477-482

[30] Islam S.M., Hussain R.R., Morshed M.A.Z., 2012. Fibre-reinforced concrete incorporating locally available natural fibres in normal- and high-strength concrete and a performance analysis with steel fibrereinforced composite concrete. Journal of Composite Materials, vol. 46(1): 111-122.

[31] Ali M., Liu A., Sou H., Chouw N., 2012. Mechanical and dynamic properties of coconut fibre reinforced concrete, Construction and Building Materials, vol. 30: 814-825.

[32] Othuman Mydin M.A., Mohd Zamzani N., 2018. Coconut fiber strengthen high performance concrete: Young's modulus, ultrasonic pulse velocity and ductility properties. International Journal of Engineering and Technology (UAE), vol. 7(2): 284-287 